PART 1

Toward Education for Climate Action as the Priority 
Alyssa Dougherty - 9789004471818

Downloaded from Brill.com04/26/2023 04:34:20AM via free access 


\title{
A Student Reflects on Her US Environmental Education
}

\author{
Alyssa Dougherty
}

\begin{abstract}
The $\mathrm{K}-12$ education system in the United States falls short on climate education. This chapter will contrast the shortcomings of my experiences learning about the climate as a student with my greater success in acquiring understanding through pursuing the topic on my own time. Students often lack a sense of personalized learning regarding climate change, which makes it hard for them to find a change within themselves. The underlying problem is that the education system shouldn't be leaving it to the initiative of some students for other students to learn about climate change. I discuss measures that I have taken with younger students and lay out proposals for effective changes, including a national curriculum and attention to the effectiveness of voting for climate-aware candidates at all levels of government.
\end{abstract}

\section{Keywords}

student - climate change - climate change education - US climate education

Controversial aspects of climate change in the United States make it difficult for $\mathrm{K}-12$ students, regardless of their scientific backgrounds, to understand the immediate and long-term changes happening to our planet in front of our eyes.

My personal experience with climate change education in school was poor. Although they taught us some science concerning our global temperature's warming up, they didn't teach enough for me to grasp the intensity of the changes. I got a textbook definition of climate change through teaching that involved some science and little practicality. Although I have clear memories of learning about our environment, what it is, how it works, and how it contributes to human life, understanding how our environment works is very

(C) UNESCO IBE, 2021 | DOI: 10.1163/9789004471818_002

This is an open access chapter distributed under the terms of the CC BY 4.0 License.

Alyssa Dougherty - 9789004471818 
different from grasping how humans are destroying it. Teachers told us that you shouldn't litter, should recycle, and should do things like ride your bike to school. Never did we take a step back to understand that climate change is a real thing, that it is already affecting us in the present.

As an adolescent I looked at human environmental impact in only its "big picture" effects and thus blamed major corporations, factories, air travel, the meat industry, and other large institutions outside my control. I entertained some unethical thoughts, such as, "If I don't use this item, then someone else will. So I might as well". It had already been produced, the harm was done, and instead of it just going to waste, I might as well be a part of the consumption process. My mindset was obviously problematic, as were those of most of my classmates. I put my blame on the companies that manufactured single-use plastic rather than taking a step back to analyze how factors such as education shaped my personal, individual decisions.

At school I learned that the method for counteracting the use of single-use plastic was to "reduce, reuse, and recycle", with an emphasis on recycling. So I figured that if I simply threw plastic away properly, in the correct bin, it couldn't be too harmful to the environment. I did not then know that plastics I was using almost daily would not break down in my lifetime, regardless of the recycling system used. Once I pursued my education beyond the K-12 system, I was able to more accurately pinpoint how some of the inadequacies in the development of my thinking about the climate stemmed directly from lack of proper schooling on the subject.

When I was growing up in California, the people and culture around me did contribute to my having some environmental awareness. Littering is the one thing I have truly understood my personal impact upon since I was a child. When I drop a piece of trash on the ground, my brain automatically thinks of how it could potentially affect marine life, end up floating in the ocean, and trash our beaches. I had an appreciation of marine life and ocean health. But this upbringing and environmental awareness weren't sufficient to provide me with a basic understanding of climate change. I still blamed climate change on factors I couldn't control, and still questioned whether my personal usage habits really made a difference.

A student who lives in a landlocked state experiences a different thought process regarding taking care of our planet than does one who lives on the coast, and it is important to acknowledge the differences. Often young children don't understand that if you litter in an interior state like Colorado or Kansas, the litter makes its way to the ocean. This is why education is essential: teaching children at a young age how their actions can affect nature. Even I, once I got older, implemented certain changes as my appreciation for the ocean grew and grew. 
Not until college did I absorb the reality of climate change, along with trying to change my behavior. Changes can easily be added to a daily routine. This is what I started doing at first as a college student. Purchasing a reusable water bottle that I customized with stickers made reusing actually enjoyable. I liked refilling my bottle rather than wasting countless plastic bottles. I also tried to be more active, using stairs rather than the elevator, biking rather than driving. Such little things genuinely changed my life while simultaneously helping our environment.

At some point, I started to actually learn what climate change was through personal research, apart from schoolwork, and I began to live my life with a greater sense of the power behind my actions. My research was mostly through online videos, inspired particularly by seeing a local newscast about coral reefs' dying off.

I had learned that fossil fuel emissions hurt our environment, but I hadn't understood that the US economy runs on the factories that emit these fuels, which is a much deeper concept, one tied to economics and a political agenda. I came upon this agenda by chance, through informal family discussions, newspapers, and online articles.

Doors opened as I took research into my own hands. But that approach is ultimately a problem. US students shouldn't have to rely on self-sufficiency and personal research in order to get access to truth. Not everyone has the inner motivation to go out of their way to research a topic while also handling the demands of school. Our education system shouldn't be leaving it up to its students to learn about climate change on their own.

I began a journey of adopting climate activism in my college community. I spread knowledge to others through conversation, reaching out to professors, graduate students, and classmates. Through this activity, I got confirmation of this truth: US schooling is focused on teaching students about the "little things" and isn't properly informing students about the complex realities of climate change. The reality is that our economy is so tied up in the economics of burning coal, oil, and gas for economic gain that we ignore the evidence and rapid change happening to our planet.

\section{$3 \quad$ Covid-19 Opened Up Some Opportunities}

Daily routines at college changed quickly when the recent outbreak of Covid19 forced people to shelter in place for a matter of months. At college we adapted to a new realm of online schooling. And through news broadcasts, 
social media, and Zoom classroom discussions, people learned that staying home made a difference in the amount of pollution humans produce. As hundreds of millions of people stayed home, fewer cars were being driven, tourism was declining, and overall carbon emissions were reduced.

However, plastic pollution increased, as quantities of protective gloves and masks were rapidly produced to keep people safe, and people ordered heavily packaged food or other essential needs online because they feared leaving their houses. Gloves and masks were found littered throughout nature. That aspect was devastating.

This new concrete awareness of the effects of daily actions on the climate fueled my passion to help further educate others and help other students understand the impact that their carbon footprint exerts. At some point I thought to myself, "How can I spread this knowledge to students like I was when I was younger? What things do I wish I had understood about climate change at a younger age?" I look back on how my life choices would have been different if I had understood better how much of an impact I make individually.

My search for opportunities to act on climate change led me to join elementary classrooms via Zoom and making my case. The pandemic offered opportunities to educate students from all over the world about the environment through technology. I took content that I had learned so far during my college years and relayed it to the younger generation, things I wish I had known as a $\mathrm{K}-12$ student.

One of the main lessons I offered for kids bored at home in quarantine involved my leading them through the outdoors with my guided conversation of the surrounding climate change (I was actually outdoors; they were home on Zoom). In one instance, I showed them a modern Southern California harbor, filled with boats, restaurants, and surf shops. My phone camera became the students' "eyes" and "ears" for exploration when they didn't otherwise have the opportunity to explore. My topic was how human infrastructure and development have affected the waves, nature, and marine life in ways one wouldn't have thought. The harbor brings in a lot of revenue to the community, which is an economic benefit. Many people love visiting harbors as tourists because of all the amenities in one beautiful location. It is easy to forget, however, the impact and harm to the environment of human development. I focused on specifically how the harbor had disrupted natural wave forms, air quality, and original land mass. The root of the problem is an emphasis on revenue from tourism, without consideration of the associated environmental consequences.

Our society needs better, more consistent, and more easily accessible information on topics like these, including the increasing fossil fuel emissions; hot summer temperatures that keep us indoors; tornados, thunderstorms, and 
tsunamis that wipe out cities; sea level rise; killing off of plankton and algae, from which we get much oxygen; worsening health.

\section{We Can Do Better}

Without a doubt, many devastating consequences are associated with climate change. However, alongside them is the fact that there are actions students can take to help as individuals, such as reducing single-use plastic, commuting to places in a cleaner, more efficient way (biking, carpooling, or public transportation), and overall making a conscious effort to produce less waste.

On a larger scale, the importance of voting on a policy level is where one can see some of the more direct impacts of climate change. Getting out and voting is one of the most beneficial aspects of living in the United States, especially voting for a candidate who acknowledges and supports funding climate change through education. High school taught me that the importance of voting included paying attention not only to presidential campaigns, but also to each ballot proposition, midterm election, major candidate, and so on. Changes happen at the level of local government throughout the country, as well as at the national level. My experience learning about voting in school was through introductory government and history courses. We learned the history of voting in this country, how policies are made, and what we can do as future adults going into the real world. I often wish that more of my science teachers had emphasized the importance of voting while we were at school by discussing how current propositions, candidates, and mayors would set a pace for climate policies. Although my history and government teachers educated us on patterns and trends of voting in different states when it comes to the climate, learning hands-on in science classes would have been educational. I almost felt like teachers were held to too-strict guidelines to be able to have open conversations about the topic.

As a student, my idea for Congress regarding climate change would be to issue mandated climate change school curricula. States such as New Jersey have adopted climate change education. However, not all 50 states have a uniform national curriculum. There needs to be uniformity in public education within the country in order to see solid change.

Unfortunately, something as simple as this is a matter of controversy in our country. Again, the reality is that economics are driven by factories that release harmful chemicals into our atmosphere, excess plastic consumption, oil, cars, and so on. Money is circulated through these means, which is why many states are hesitant to inject the topic into their school curricula. But gaining an 
unbiased perspective during $\mathrm{K}-12$ schooling would have been beneficial for me growing up, and collaboratively the people of this country have the power to make a change through the use of education on climate change. This should be our number-one priority, even though politics tends to get in the way.

Education is powerful. Fueling fellow students with facts can lead to direct, passionate change. It doesn't come easy, but at this point there is no other option for our world. Our $\mathrm{K}-12$ schooling system has an obligation to make this difficult adjustment toward climate change education in order to properly equip students with the knowledge and power to make further change. The education system shouldn't leave it to the initiative of students to learn on their own about climate change but should provide proper stepping stones to allow students to then branch off on their own and create lifelong choices with regard to the world we live in. We must educate the future generations correctly, because Earth depends on it. 